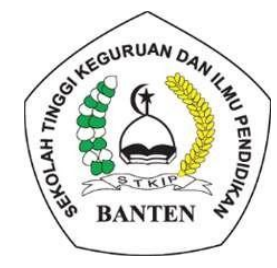

Tulip 10 (2) (2021) : 63-68

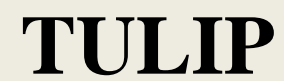

(Tulisan Ilmiah Pendidikan)

Jurnal IImiah Keguruan Dan IImu Pendidikan http://journal.stkipbanten.ac.id/index.php/tulip

\title{
STUDI LITERATUR LATIHAN CIRCUIT TRAINING TERHADAP KECEPATAN LARI SPRINT 100 METER PADA CABANG OLAHRAGA ATLETIK
}

\author{
R. Eko Santoso. ${ }^{1}$ Pardiman. $^{2}$, dan Diana Setiyani ${ }^{3}$ \\ ${ }^{1}$ Sekolah Tinggi Keguruan dan Ilmu Pendidikan Banten \\ ${ }^{2}$ Sekolah Tinggi Keguruan dan Ilmu Pendidikan Banten \\ ${ }^{3}$ Mahasiswa Pendidikan Jasmani Kesehtan dan Rekreasi \\ Penulis Korespondensi: ekosantoso1811@gmail.com ${ }^{1}$, pardiman727@gmail.com ${ }^{2}$, \\ dianasetiyani7@gmail.com ${ }^{3}$ \\ Artikel : \\ Studi Literatur Latihan Circuit training Terhadap Kecepatan Lari Sprint 100 Meter Pada \\ Cabang Olahraga Atletik \\ Penerima: Juli, 2021 \\ Diterima: Agustus, 2021 \\ Dipublikasikan: September, 2021
}

\begin{abstract}
Circuit training is an exercise system that can simultaneously improve the overall fitness of the body, namely the elements of power, endurance, strength, agility, speed, and other physical components. tactical, and mental that must be considered is the quality of the physical condition. Physical conditions affect the implementation of techniques, the application of tactics and mental maturity. The purpose of this study was to determine the study of the circuit training exercise literature on the speed of the 100 meter sprint in athletics. The research method used is a literature study consisting of several sources such as primary sources and secondary sources. The results obtained from the research that has been done that circuit training exercises have a positive effect on the speed of running 100 meters. The positive effect is shown by the increase in students' running speed.
\end{abstract}

Keywords: Circuit Training, Speed, Sprint

\begin{abstract}
ABSTRAK
Circuit training adalah suatu sistem latihan yang dapat memperbaiki secara serempak fitness keseluruhan dari tubuh, yaitu unsur-unsur power, daya tahan, kekuatan, kelincahan, kecepatan, dan komponen fisik yang lain, Dalam perlombaan lari untuk dapat mencapai hasil yang maksimal, selain teknik, taktik, dan mental yang harus diperhatikan adalah kualitas kondisi fisik. Kondisi fisik berpengaruh terhadap pelaksanaan teknik, penerapan taktik maupun kematangan mental. Tujuan penelitian ini adalah untuk mengetahui studi literatur latihan circuit training terhadap kecepatan lari sprint 100 meter pada cabang olahraga atletik. Metode penelitian yang digunakan adalah penelitian studi literatur yang terdiri dari beberapa sumber seperti sumber primer dan sumber sekunder. Hasil yang didapatkan dari penelitian yang telah dilakukan bahwa latihan circuit training memiliki pengaruh yang positif terhadap kecepatan lari 100 meter. Pengaruh positif tersebut ditunjukan dengan meningkatnya kecepatan lari siswa.
\end{abstract}

Kata kunci: Latihan Circuit Training, Kecepatan, Lari Sprint

\section{PENDAHULUAN}

(C) 2021, Tulip, Jurnal Tulisan Ilmiah Pendidikan. STKIPB

e-ISSN: 2807-4114 
2 R. Eko Santoso, Pardiman², dan Diana Setiyani³, Studi

Literatur Latihan Circuit Training Terhadap Kecepatan Lari Sprint 100

Meter Pada Cabang Olahraga Atletik

Atletik merupakan suatu cabang olahraga tertua dan juga dianggap sebagai induk dari semua cabang olahraga. Menurut Tamsir Riyadi Atletik merupakan cabang olahraga yang terdiri atas nomor lari, lompat dan lempar. Gerak-gerak yang terdapat dalam cabang olahraga atletik seperti: berjalan, berlari,melompat dan melempar adalah gerak yang di lakukan oleh manusia di dalam kehidupan sehari-hari ${ }^{1}$.

Atletik merupakan salah satu cabang olahraga yang cukup popular di kalangan masyarakat kita, hal ini dibuktikan dengan antusiasme masyarakat dalam mengikuti perlombaan yang sering diadakan baik ditingkat daerah maupun nasional ${ }^{2}$. Mereka berpartisipasi sebagai peserta perlombaan atletik diberbagai nomor maupun sebagai penonton perlombaan. Sebagai peserta perlombaan, mereka yang mempunyai motivasi berbeda. Ada yang mempunyai motivasi untuk prestasi olahraga, ada juga yang mempunyai motivasi untuk menyalurkan hobi ataupun hanya ikut serta memeriahkan perlombaan atletik tersebut, sebagai penonton mereka memberikan semangat dan dukungan moral. Perkembangan atletik di tanah air juga ditandai dengan banyaknya klub-klub atletik di bawah naungan PASI. Klub-klub tersebut saling bersaing dalam membina atletnya untuk berprestasi dalam bidang olahraga khususnya atletik.

Dijenjang pendidikan yang mengajarkan atletik pada mata pelajaran pendidikan jasmani, olahraga, dan kesehatan khususnya di tingkat Sekolah Menengah Pertama (SMP). Setiap pembelajaran atletik tidak membutuhkan peralatan modern, cukup dengan peralatan sederhana yang dapat dimodifikasi oleh guru dan siswa secara bersama-sama. "Dalam setiap kegiatan pendidikan jasmani dan olahraga guru selalu menggunakan atletik sebagai pembuka, inti atau penutup

\footnotetext{
${ }^{1}$ Riyadi, Tamsir. (2015). Petunjuk Atletik. Yogyakarta cetakan II. Yogyakarta.

${ }^{2}$ Dwi, R. Septiana. (2017). Peningkatan Kemampuan Lari Sprint Dengan Menggunakan Metode Latihan Lari di Pasir Pada Siswa Peserta Ekstrakurikuler Atletik SMK Negeri 1 Gombong Kabupaten Kebumen Program S1 pendidikan Jasmani Kesehatan dan Rekreasi UNY. Skripsi
}

(C) 2021, Tulip, Jurnal Tulisan Ilmiah Pendidikan. STKIPB e-ISSN: $2807-4114$ kegiatan belajar mengajar" ${ }^{3}$. Dikarenakan atletik salah satu materi pendidikan jasmani yang efektif untuk mengoptimalkan pertumbuhan dan perkembangan siswa.

Realita di lapangan, berdasarkan hasil penelitian di MIS Nurul Yaqiin Kota Tanggerang, Pada cabang olahraga atletik khususnya lari sprint 100 Meter pada sebagian besar siswa belum mampu menyelesaikan lari sprint dengan waktu minimal 00,00-16,05 (putra) dan 00,00-17,00 (putri $)^{4}$. Dikarenakan siswa tidak melakukan teknik start jongkok, teknik berlari yang baik, tidak mau melakukan aktivitas fisik, saat lari sprint dilaksanakan pada siang hari dengan cuaca yang panas dan siswa mengalami kelemahan pada kondisi fisiknya ${ }^{5}$. Berdasarkan permasalahan tersebut, hipotesa peneliti bahwa Circuit training dapat memperbaiki lari sprint 100 meter siswa.

Circuit training dapat dilakukan pada suatu ruangan atau tempat dimana telah ditetapkan jumlah pos/stasion dengan latihan-latihan yang berbeda ${ }^{6}$. Penerapan circuit training merupakan salah satu program latihan fisik yang sangat mudah untuk dilakukan dan tidak memakan waktu yang lama, dalam bentuk latihannya terdiri dari berbagai macam latihan fisik yang dilakukan secara terus menerus tanpa ada waktu istirahat, diketahui waktu latihannya dalam menyelesaikan dosis yang telah ditentukan, diketahui bobot intensitas latihannya dapat ditingkatkan dengan pengulangan atau menambah pos, tempat latihannya dapat disesuaikan diberbagai area, alatnya mudah didapat, dan tidak menghabiskan waktu banyak. Melalui circuit training dapat meningkatkan aktivitas fisik dan kondisi fisik siswa.

Lari cepat atau jarak sprin 100 meter merupakan nomor lari dalam cabang olahraga atletik. Yang dimaksud dengan lari jarak sprint adalah semua nomor lari yang

\footnotetext{
${ }^{3}$ Indik, Endang Sunarya, Bastinus N. Matjan, Aming Supriyatna, et al. (2019). Pendidikan

Jasmani dan Olahraga, Bandung: Universitas Pendidikan Indonesia.

${ }^{4}$ Syaifar Zun Salwa. 2018. Pengaruh Circuit Taining

Terhadap Lari Sprint 100 Meter pada Siswa

${ }^{5}$ Ibid, Hal 28

${ }^{6}$ Engkos Kosasih. (2015). Olahraga, Teknik dan

Program Latihan. Jakarta: CV. Akademika Pressindo.
} 
dilakukan dengan kecepatan penuh (kecepatan maksimal) sepanjang jarak yang harus ditempuh ${ }^{7}$.

Berdasarkan pada latar belakang masalah, maka dapat diidentifikasi masalah penelitian sebagai berikut:

1. Siswa tidak dapat melakukan lari sprint 100 meter dengan waktu cepat.

2. Pada saat melakukan lari sprint 100 meter ada sebagian besar siswa tidak dapat menyelesaikan lari sprint 100 meter dengan waktu yang singkat.

Selanjutnya berdasarkan latar belakang yang telah diuraikan di atas, peneliti merumuskan masalah sebagai berikut : "Bagaiman potensi latihan circuit training terhadap kecepatan lari sprint 100 meter pada cabang olahraga atletik"?

Adapun tujuan dari penelitian ini adalah untuk mengetahui potensi latihan circuit training terhadap kecepatan lari sprint 100 meter pada cabang olahraga atletik.

Berikutnya manfaat dari penelitian ini yaitu sebagai berikut:

1. Manfaat Teoritis

Sebagai sarana untuk menambah referensi dan sebagai bahan acuan untuk pembelajaran atletik sehingga dapat meningkatan kualitas sumber daya manusia, khususnya dalam olahraga permainan atletik.

2. Manfaat Praktis

a. Bagi Peserta didik, hasil ini diharapkan agar dapat digunakan sebagai bahan acuan untuk meningkatkan keterampilan lari sprint pada cabang olahraga atletik.

b. Bagi pihak sekolah, hasil ini dapat digunakan sebagai bahan acuan dalam usaha untuk peningkatan kecepatan lari sprint.

c. Bagi Guru, dapat mengetahui seberapa tinggi tingkat keterampilan Lari Sprint pada cabang olahraga para siswanya dan hasil Penelitian ini diharapkan dapat digunakan sebagai acuan untuk pembelajaran atletik di sekolah.

d. Bagi Penulis, dapat menambahkan pemahaman mengenai hal-hal berhubungan dengan teori lari Sprint,

7 Sugiyono, Trisyono, Bambang Sugeng, Eddy Suprayitno, et al., (2015). Pendidikan Jasmani dan Kesehatan, Cet ke-1. Jakarta: Penerbit Yudhistira.

(C) 2021, Tulip, Jurnal Tulisan IImiah Pendidikan. STKIPB e-ISSN: $2807-4114$
serta faktor-faktor
yang
mempengaruhi lari Sprint pada cabang olahraga atletik.

\section{LANDASAN TEORI}

Atletik merupakan suatu cabang olahraga tertua dan juga dianggap sebagai induk dari semua cabang olahraga. Menurut Tamsir Riyadi Atletik merupakan cabang olahraga yang terdiri atas nomor lari, lompat dan lempar. Gerak-gerak yang terdapat dalam cabang olahraga atletik seperti: berjalan, berlari,melompat dan melempar adalah gerak yang di lakukan oleh manusia di dalam kehidupan sehari-hari ${ }^{8}$.

Atletik merupakan salah satu cabang olahraga yang cukup popular di kalangan masyarakat kita, hal ini dibuktikan dengan antusiasme masyarakat dalam mengikuti perlombaan yang sering diadakan baik ditingkat daerah maupun nasional ${ }^{9}$. Mereka berpartisipasi sebagai peserta perlombaan atletik diberbagai nomor maupun sebagai penonton perlombaan. Sebagai peserta perlombaan, mereka yang mempunyai motivasi berbeda. Ada yang mempunyai motivasi untuk prestasi olahraga, ada juga yang mempunyai motivasi untuk menyalurkan hobi ataupun hanya ikut serta memeriahkan perlombaan atletik tersebut, sebagai penonton mereka memberikan semangat dan dukungan moral. Perkembangan atletik di tanah air juga ditandai dengan banyaknya klub-klub atletik di bawah naungan PASI. Klub-klub tersebut saling bersaing dalam membina atletnya untuk berprestasi dalam bidang olahraga khususnya atletik.

Istilah atletik yang kita kenal sekarang ini berasal dari beberapa sumber antara lain bersumber dari bahasa Yunani, yaitu "athlon" yang mempunyai pengertian berlomba atau bertanding. Misalnya ada istilah pentathlon atau decathlon. Atletik yang diperlombakan ialah nomor-nomor:

\footnotetext{
${ }^{8}$ Riyadi, Tamsir. (2015). Petunjuk Atletik. Yogyakarta cetakan II. Yogyakarta.

${ }^{9}$ Dwi, R. Septiana. (2017). Peningkatan Kemampuan Lari Sprint Dengan Menggunakan Metode Latihan Lari di Pasir Pada Siswa Peserta Ekstrakurikuler Atletik SMK Negeri 1 Gombong Kabupaten Kebumen Program S1 pendidikan Jasmani Kesehatan dan Rekreasi UNY. Skripsi
} 
4 R. Eko Santoso, Pardiman², dan Diana Setiyani³, Studi

Literatur Latihan Circuit Training Terhadap Kecepatan Lari Sprint 100

Meter Pada Cabang Olahraga Atletik

jalan, lari, lompat dan lempar. Event-event lari kadang-kadang dikatakan sebagai masalah non-teknis, ini hanya karena lari adalah suatu aktivitas alami yang Nampak relatif sangat sederhana ${ }^{10}$, bila dibandingkan dengan event lompat tinggi galah atau lontar martil. Namun, tidaklah ada sesuatu yang sederhana/ simple tentang event lari dalam atletik.

Event dalam nomor lompat dalam atletik mungkin nampak berbeda antara satu dengan yang lainnya. Dari sudut pandang teknik mereka membentang dari lompat jauh yang relatif sederhana sampai ke lompat tinggi dan lompat jangkit sampai dengan event yang komplek lompat tinggi galah ${ }^{11}$.

\section{METODE}

Sugiono dalam Suarifqi menyatakan bahwa Metode penelitian pada dasarnya merupakan cara ilmiah untuk mendapatkan data dengan tujuan dan kegunaan tertentu ${ }^{12}$. Desain penelitian ini menggunakan pendekatan kualitatif. Pendekatan kualitatif desainnya bersifat umum, dan berubah-ubah atau berkembang sesuai dengan situasi di lapangan. Sebagaimana yang dijelaskan oleh Sugiyono bahwa "metode ini disebut juga dengan metode interpretive karena data hasil penelitian lebih berkenaan dengan interpretasi terhadap data yang ditemukan di lapangan". ${ }^{13}$

Jenis penelitian ini adalah penelitan kepustakaan (Library Research), penelitian kepustakaan yaitu serangkaian penelitian yang berkenaan dengan metode pengumpulan data pustaka, atau penelitian yang obyek penelitiannya digali melalui beragam informasi kepustakaan baik itu buku, ensiklopedi, jurnal ilmiah, koran, majalah, dan dokumen-dokumen lainnya ${ }^{14}$.

\footnotetext{
${ }^{10} \mathrm{Ibid}$, Hal 80

${ }^{11} \mathrm{Ibid}, \mathrm{Hal} 82$

12 Suarifqi Diantama. Metode Penelitian Pendidikan.(Pustaka Rahmat.Bandung, 2018)..h.19

13 Sugiyono, Metode Penelitian Kombinasi (Mixed Method), (Bandung: Alfabeta, 2011), h. 12.

${ }^{14}$ Pardiman. 2020. Kemampuan Kecepatan Lari 100 Meter Melalaui Latihan Interval Training. JurnaSportif

(C) 2021, Tulip, Jurnal Tulisan Ilmiah Pendidikan. STKIPB e-ISSN: $2807-4114$
}

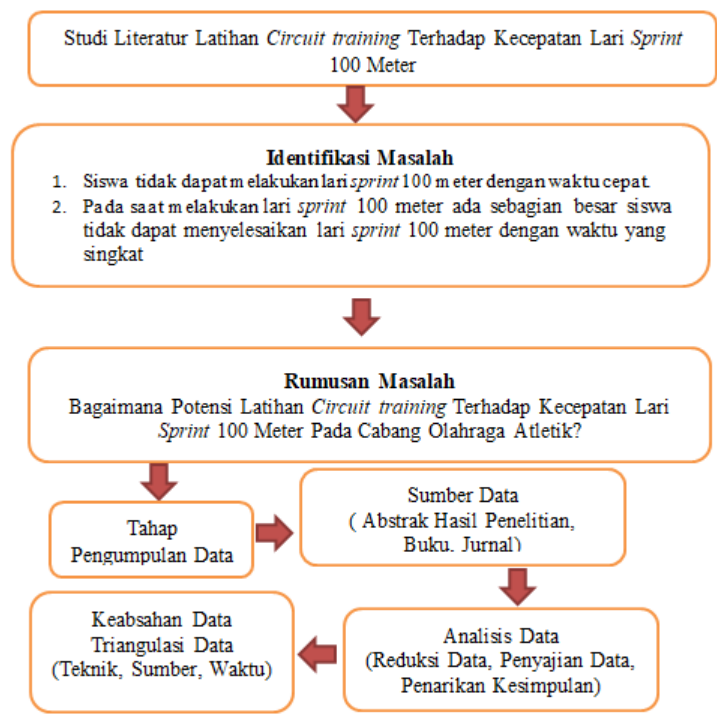

\section{HASIL DAN PEMBAHASAN}

Penelitian ini dilakukan untuk mengetahui potensi latihan circuit training terhadap kecepatan lari sprint 100 meter. Berdasarkan sumber-sumber yang relevan menunjukkan adanya potensi latihan circuit training terhadap kecepatan lari sprint 100 meter. Hal ini dilihat dari meningkatnya kecepatan lari sprint 100 meter. Berikut merupakan penjelasan dari sumber-sumber yang telah didapatkan bahwasanya adanya peningkatan kecepatan lari sprint 100 meter menggunakan latihan circuit training. Ratarata persentase kecepatan lari sprint 100 meter menggunakan latihan circuit training mulai dari yang terendah 2.9 sampai dengan 27.09 dengan memperoleh jumlah peningkatan 145.98 Hal ini dapat disimpulkan bahwa adanya pengaruh latihan circuit training terhadap kecepatan lari sprint 100 meter.

Berdasarkan hasil analisis keseluruhan dari tabel data jurnal kecepatan lari sprint 100 meter diatas dapat dilihat hasil penelitian keseluruhan tabel bahwa persentase meningkat dari sebelum menggunakan latihan latihan circuit dan setelah latihan circuit training. Dengan menggunakan metodelogi penelitian Eksperimen. Metode Eksperimen dengan latihan pre-test dan post test yang mengalami persentase yang sangat meningkat. Dapat disimpulkan bahwa dengan latihan circuit training dapat meningkatkan kecepatan lari sprint 100 meter. 
Hasil analisi dapat dilihat bahwa setiap penelitian yang telah dilakukan memperoleh hasil persentase yang menujukkan adanya peningkatkan dalam kecepatan lari sprint 100 meter, bisa dilihat dari diagram dibawah ini :

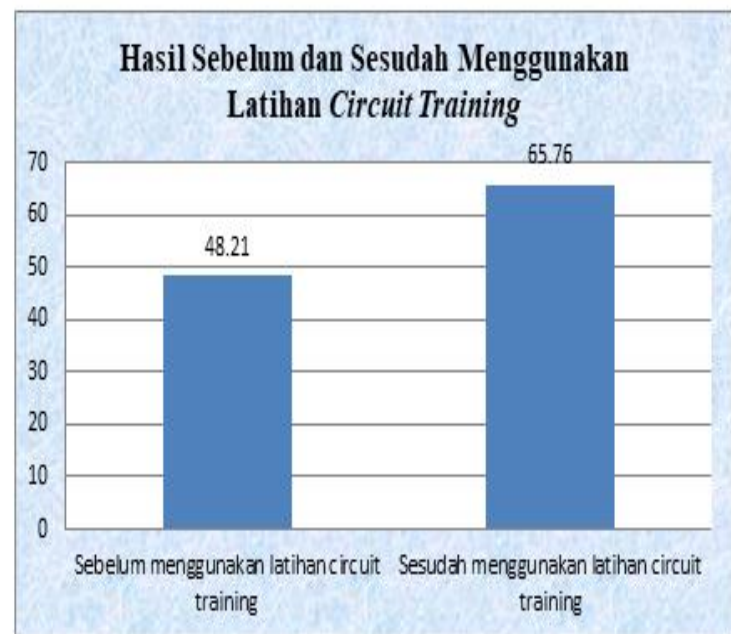

Adapun rata-rata hasil sebelum menggunakan latihan circuit training yaitu 48.21 dan sesudah menggunakan menggunakan latihan circuit training meningkat menjadi 65.76. Dari hasil penelitian yang dilakukan peneliti-peneliti sebelumnya bahwa menggunakan latihan circuit training dapat meningkatkan kecepatan lari 100 meter. Dari data yang sudah dianlisis terdapat bahwa adanya perbedaan kenaikan persentase kecepatan lari 100 meter dalam jurnal tersebut terkait latihan latihan circuit training.

\section{PENUTUP}

\section{Simpulan}

Dengan demikian hasil penelitian ini dapat disimpulkan bahwa latihan circuit training dapat berpotensi positif terhadap kecepatan lari 100 meter. Hal ini terbukti pada penelitian yang telah dilakukan oleh beberapa peneliti yang terdahulu. Hasil dari penelitian yang menggunakan metode penelitian eksperimen juga meiliki hasil penelitian yang berpotensi positif dalam kecepatan lari.

Hasil yang didapatkan dari penelitian yang telah dilakukan bahwa latihan circuit training memiliki potensi yang positif terhadap kecepatan lari 100 meter. Pengaruh positif tersebut ditunjukan dengan meningkatnya kecepatan lari siswa maupun atlet tersebut. Hal tersebut berdasarkan hasil penelitian terdahulu yang didasari penghitung (c) 2021, Tulip, Jurnal Tulisan Ilmiah Pendidikan. STKIPB e-ISSN: $2807-4114$ statistik maupun presentase.

\section{Saran}

Berdasarkan kesimpulan di atas, dapat diusulkan saran yang diharapkan akan bermanfaat bagi penelitian selanjutnya:

1. Bagi Instansi Terkait

Dinas Pendidikan dan Sekolah untuk senantiasa meningkatkan Sumber Daya Manusia, sarana dan prasarana maupun perangkat dalam pembelajaran tentang konsep-konsep pembelajaran yang menarik perhatian siswa.

2. Bagi Siswa

Siswa hendaknya dapat lebih meningkatkan kemampuan melalui latihan circuit training sehingga siswa dapat melakukan teknik lari dengan kemampuan yang baik untuk mendukung hasil belajarnya.

3. Bagi Peneliti Selanjutnya

a. Bagi peneliti selanjutnya yang tertarik untuk melakukan kajian di bidang yang sama dapat menambah variabel independen maupun dependen yang memiliki kemungkinan pengaruh kecepatan lari 100 meter.

b. Peneliti selanjutnya disarankan untuk menambah jumlah sumber referensi sehingga penelitian dapat digeneralisasikan dengan baik.

\section{DAFTAR PUSTAKA}

Adi, Wunendra, Kharisma Jati, dan Joe Manuk, eds. (2018). Atletik. Yogyakarta: Pustaka Insan Madani

Arendi Aprilian pada tahun 2018 yang berjudul "Pengaruh Latihan Circuit training dengan Kecepatan Lari Sprint 100 Meter Siswa SMP Negeri 10 Kota Bengkulu."

Arifin, Zaenal. (2016). Evaluasi Pembelajaran, Bandung: PT Remaja Rosdakarya.

Arifin, Zainul Djedje, M.P. Sianipar, Herry Nugraha, Diding Rochandi, dan Tjik Ayu Mursyid eds. (2015). Pendidikan Jasmani 
6 | R. Eko Santoso, Pardiman², dan Diana Setiyani³, Studi

Literatur Latihan Circuit Training Terhadap Kecepatan Lari Sprint 100

Meter Pada Cabang Olahraga Atletik

dan Kesehatan. Cet ke-2. Jakarta:

PT Aries Lima.

Dea Linia Romadhoni pada tahun 2015

yang berjudul "Pengaruh

Pemberian Circuit training

Terhadap Peningkatan Kecepatan

Lari Sprint 100 Meter."

Fachrizal pada tahun 2014 yang berjudul "Pengaruh Latihan Circuit training Terhadap Kecepatan Lari Sprint Siswa SMP Negeri 6 Kota Lhokseumawe."

Fachrizal, (2015) "Hubungan Power Otot Tungkai dengan Kecepatan Lari Sprint Siswa SMP Negeri 6 Kota Lhokseumawe",

Harsono, (2015). Kepelatihan Olahraga Teori dan Metodologi, Cet ke-1, Bandung: PT Remaja Rosdakarya.

Hudah, M., (2019). Pengaruh Metode Circuit training Terhadap Kecepatan Lari Sprint SMA N 1 Pegandon.

Indik, Endang Sunarya, Bastinus N. Matjan, Aming Supriyatna, Sumardiyanto, Badruzaman, dan Supardi, et al. (2019). Pendidikan Jasmani dan Olahraga. Bandung: Universitas Pendidikan Indonesia.

Irianto, Pekik Djoko. (2014). Bugar dan Sehat. Yogyakarta: Andi Offset.

Jamaludin, R., (2019). Circuit training Meningkatkan Kecepatan Lari Siswa SMA Negeri 1 TOJO UNAUNA. 